\title{
ПРАВОВОЕ РЕГУЛИРОВАНИЕ ОТВЕТСТВЕННОСТИ ЗА ЭКОЛОГИЧЕСКИЕ ПРЕСТУПЛЕНИЯ В СФЕРЕ ОБРАЩЕНИЯ С ОТХОДАМИ. РОССИЙСКИЙ И МЕЖДУНАРОДНЫЙ ОПЫТ
}

\begin{abstract}
Аннотация: В статье приводится анализ мер противодействия нарушениям правил обращения $c$ отходами и предупреждению их негативного влияния на окружающую среду и здоровье человека. $B$ статье исследуются вопросы административной уголовной и дисииплинарной ответственности за правонарушения в сфере обращения с отходами. Рассматриваются как акты федерального уровня регулирующие данную ответственность так и акты регионального уровня (например законы города Москва). Автор приводит статистические данные по преступлениям в сфере обращения с отходами. В статье также исследуется зарубежный опыт борьбы с экологическими преступлениями и анализируется его эффективность. Также исследуется опыт борьбы с экологическими преступлениями на международном и европейском уровнях. В статье используются классические для юридической науки методы исследования : общиий логический, сравнительно-правовой, синтеза и анализа и т.п. Обеспечение правопорядка и законности при обращении с отходами в целом и с различными их видами, в том числе опасными, радиоактивными, биологическими, бытовыми, строительными и др., в последние десятилетия ХХ века стало признаваться одной из наиболее острых проблем как экологического, так и уголовного права. Как следствие автор рассматривает различные предложения по совершенствованию уголовного закона и предлагает собственные решения по совершенствованию законодательных норм в сфере борьбы с экологическими правонарушениями.

Abstract: This article analyzes the measures taken with regards to violations of waste disposal regulations and warns on their negative impact on the environment and human health. The article examines the issues of administrative, criminal and disciplinary accountability for violations pertaining to waste disposal. It reviews federal acts that regulate this responsibility, as well as acts functioning on a regional level. This work presents international experience on the fight against environmental crimes and analyzes its effectiveness. The methods used in this research are classical for jurisprudence: general logical, legal comparative, synthesis and analysis, etc. The author examines various proposals on improving the criminal law and suggests his own solutions on perfecting the legislative norms on the fight against the environmental infractions. Ключевые слова: Опасные отходы, экологические преступления, криминологическая ситуачия, незаконная торговля отходами, конфликты, правовое регулирование, уголовное право, административное право, международное право, тенденции правонарущений.
\end{abstract}

Keywords: Hazardous waste, environmental crimes, criminological situation, illegal sale of waste, conflicts, legal regulations, criminal law, administrative law, international law, tendencies of infractions.

Определение экологических преступлений и правонарушений, а также ответственности за их совершение в российском законодательстве.

аконом РСФСР от 19 декабря 1991 г. «Об охране окружающей природной среды» впервые приведено определение экологического преступления - это «общественно опасное деяние, посягающее на установленный в Российской Федерации экологический правопорядок, экологическую безопасность общества и причиняющее вред окружающей природой среде и здоровью человека. За экологические правонарушения, то есть противоправные деяния, нарушающие природоохранное законодательство и причиняющие вред окружающей природной среде и здоровью человека, должностные лица и граждане несут дисциплинарную, административную либо уголовную, гражданскоправовую, материальную, а предприятия, учреждения и организации - административную и гражданскоправовую ответственность». 
Это легитимное определение не было воспроизведено ни в УК РФ, ни в Федеральном законе «Об охране окружающей среды» № 7-ФЗ от 7 января 2002 г.

Статьей 75 Закона от 7 января 2002 года установлены следующие главные виды ответственности за нарушение законодательства в области охраны окружающей среды: имущественная, дисциплинарная, административная и уголовная ответственность.

Имущественная ответственность - это применение к правонарушителю принудительных мер воздействия, имеющих отрицательные имущественные последствия. Она регулируется ГК РФ (ст. 15, гл. 59 и др.).

Дисциплинарная ответственность - это применение к совершившему дисциплинарный проступок работнику дисциплинарных взысканий, установленных в Трудовом и Гражданском кодексах РФ.

Общая дисциплинарная ответственность применятся к работникам по правилам, установленным ГК РФ от 30 декабря 2001 г., а специальная - в соответствии с уставами, правилами внутреннего трудового распорядка и пр. Согласно статье 192 ГК РФ дисциплинарными взысканиями являются замечание, выговор, увольнение.

Административная ответственность - это самостоятельный вид юридической ответственности, наступающей при наличии всех признаков состава административного проступка, предусмотренного КоАП РФ или законами субъектов Федерации об административных правонарушениях, содержащих соответствующие запреты и санкции (административные наказания).

Административная ответственность регулируется КоАП РФ (гл. $7,8,10)$ и законами субъектов Российской Федерации. Например, Закон г. Москвы от 21 ноября 2007 г. № 45 «Кодекс города Москвы об административных нарушениях» в главе 4 «Административные правонарушения в области охраны окружающей среды и природопользования» содержит 49 статей, в том числе устанавливающих ответственность за нарушение экологических требований при эксплуатации очистных сооружений и сетей ливневой канализации; сброс или размещение снега вне специально отведенных мест хранения и удаления; ввоз и использование почвогрунтов, не соответствующих экологическим требованиям, и т.д. Отдельные составы содержатся в главах об административных правонарушениях в области землепользования; градостроительства и эксплуатации объектов городской инфраструктуры; в области благоустройства города и в области обращения с животными.

Уголовная ответственность - это самостоятельный вид юридической ответственности, устанавлива- емый только Уголовным кодексом РФ за совершение проступка, содержащего все признаки состава преступления. К нему относится виновное, противоправное общественно опасное деяние (действие или бездействие), посягающее на окружающую среду и ее компоненты, качества, свойства, состояние, использование и охрана которых обеспечивают жизнедеятельность человека, на экологическую безопасность населения и территорий, влекущее причинение экологического вреда окружающей среде, здоровью человека, иным охраняемым правом благам либо создающее угрозу причинения вреда.

Составы экологических преступлений в основном содержатся в главе 26 Кодекса.

Таким образом, юридическая ответственность за экологические правонарушения регулируется КоАП РФ, законами субъектов Российской Федерации об административной ответственности, ГК РФ, УК РФ, ТК РФ, правилами внутреннего трудового распорядка и иными актами предприятий, организаций, учреждений.

\section{Криминологическая ситуация в области нарушений законодательства об отходах в Российской Федерации.}

Число зарегистрированных преступлений, составы которых предусмотрены главой 26 УК РФ, составляет в общей структуре преступности около $1 \%$, хотя исследователи и фиксируют их опережающий рост по сравнению с иными преступлениями и преступностью в целом ${ }^{1}$. Среди зарегистрированных экологических преступлений большую часть составляет браконьерство различных видов. Но, на наш взгляд, чрезвычайно важен тот факт, что среди преступлений, составы которых сформулированы законодателем как загрязнение компонентов окружающей среды и нарушения правил ее охраны в ходе производственной деятельности (ст. 246-255 УК РФ), именно преступное нарушение правил обращения с отходами регистрируется чаще всего.

Значение проблем борьбы и предупреждения нарушений законодательства в данной области подтверждается ростом зарегистрированных правонарушений и преступлений по упомянутым выше статьям УК РФ и КоАП РФ.

\footnotetext{
${ }^{1}$ Подробнее об этом см.: Дубовик О.Л., Жалинский А.Э. Причины экологических преступлений. М., 1988. Комментарий к Кодексу РСФСР об административных правонарушениях / Под ред. И. И. Веремеенко, Н. Г. Самищевой, М. С. Студеникиной.. С. 249-255.
} 
DOI: $10.7256 / 1811-9018.2014 .11 .13201$

При цитировании этой статьи сноска на доі обязательна

\section{Право и политика $11(179) \cdot 2014$}

Приведем некоторые примеры для иллюстрации сказанного. Так, в 2012 г. силами МПР России при проведении государственного контроля за деятельностью в области обращения с отходами должностными лицами было возбуждено 13280 дела. Соответственно, предъявлено штрафов 4314 на сумму 189281,4 тыс. рублей ${ }^{2}$.

Для сравнения обратимся к данным по Москве. Инспекционными подразделениями Департамента природопользования и охраны окружающей среды при Правительстве Москвы в 2012 г. проводились плановые и внеплановые проверки предприятий и организаций. Всего за 2012 год указанными сотрудниками Департамента проведено 1348 плановых проверок, 174 внеплановые проверки (из них в области обращения с отходами - 3 проверки) и 144 обследования на предмет соблюдения природоохранного законодательства в области обращения с отходами. В ходе указанных мероприятий выявлено 766 нарушений требований законодательства в области охраны окружающей среды и привлечено к административной ответственности 1215 виновных лиц за нарушение природоохранного законодательства при обращении с отходами на общую сумму 76 млн. 632 тыс. руб. ${ }^{3}$

Данные об экологической преступности более тщательно собираются и анализируются в трудах специалистов в области экологического и уголовного права, криминологами. Сопоставим кратко сведения о регистрации преступлений по статье 247 УК РФ и количестве привлеченных к уголовной ответственности лиц. Если в 2001 г. было зарегистрировано 40 преступлений, в 2002 г. - 54, в 2003 г. - 58, то к уголовной ответственности, соответственно, привлечено 26, 20 и 35 лиц. Для сравнения: по ст. 250 «Загрязнение вод» число зарегистрированных преступлений составляет, соответственно, $16,12,19$, а к уголовной ответственности привлечено 8, 3 и 5 человек; по ст. 251 «Загрязнение атмосферы» зарегистрированы в этот период 6, 6 и 10 преступлений, привлечено к уголовной ответственности - 4, 3 и 8 человек. По ст. 261 «Уничтожение и повреждение лесов» УК РФ порядок цифр выглядит иначе. В 2001 г. было зарегистрировано 258 преступлений (выявлено 102 лица, совершивших преступление), в 2002 г., соответственно, 730 и 119, а в 2003 г. 2021 преступления и 129 лиц. Данные приводятся по Государственному

\footnotetext{
${ }^{2}$ Подробнее см.: Государственный доклад о состоянии и об охране окружающей среды Российской Федерации в 2012 г. М.: МПР России, 2014. С.420- 421.

${ }^{3}$ Подробнее см.: Доклад о состоянии окружающей среды в городе Москве в 2012 г. М.: Департамент природопользования и охраны окружающей среды при Правительстве города Москвы, 2013. С.63.
}

Докладу о состоянии и об охране окружающей среды в Российской Федерации в 2003 году (с.401) и, к сожалению, они не учитывают разделения на основные и квалифицированные составы.

\section{Санкции уголовно-правового и административного характера за экологические преступления, посягающие на порядок обращения с отходами.}

Специальные санкции уголовно-правового и административного характера за нарушение правил и требований при обращении с отходами стали применяться - по сравнению, например, с ответственностью за браконьерство - относительно недавно. Хотя все же возможности уголовного преследования этого вида преступлений существовали и в период действия УК РСФСР путем использования статей о должностных преступления ${ }^{4}$.

Тем не менее, Обеспечение правопорядка и законности при обращении с отходами в целом и с различными их видами, в том числе опасными, радиоактивными, биологическими, бытовыми, строительными и др., в последние десятилетия XX века стало признаваться одной из наиболее острых проблем как экологического, так и уголовного права. Специалисты разных отраслей научного знания, в частности химики, биологи, физики и, конечно, в первую очередь, юристы - представители экологического, административного и уголовного права, а также криминологи, начиная с конца 70-х гг. все чаще стали говорить об угрозах для окружающей среды и здоровья людей, возникающих вследствие ненадлежащего обращения с отходами, и о неотложности решения задач по предотвращению таких угроз. Эти задачи в настоящее время осознаны не только в рамках науки и инжиниринга, но и международным сообществом, законодателями многих стран, структурами исполнительной власти и работниками правоохранительных и природоохранных контрольнонадзорных органов. Указанная тенденция потребовала разработки, принятия и реализации специальных законодательных и иных нормативных правовых актов, регулирующих самые разные стороны обращения с различными видами отходов и устанавливающих меры уголовной и административной ответственности за нарушение действующих правил, а также обеспечения их применения и исполнения.

\footnotetext{
${ }^{4}$ Об истории уголовно-правовой борьбы с экологическими преступлениями см.: Курс российского уголовного права. Особенная часть / Под ред. В.Н. Кудрявцева и А.В. Наумова. М.: Спарк, 2002 и др. работы.
} 
DOI: $10.7256 / 1811-9018.2014 .11 .13201$

При цитировании этой статьи сноска на dоі обязательна

Человек и окружающая среда

\section{Уголовная ответственность за нарушение законодательства об отходах по УК РФ и проблемы ее совершенствования.}

Как и в других странах, в Российской Федерации в 1996 г. была проведена соответствующая реформа, и Уголовный кодекс, вступивший в действие с 1 января 1997 г., устанавливает запрет нарушения правил обращения с опасными отходами в специальной статье (ст.247), с иными отходами - в других статьях 26 главы «Экологические преступления» (например, в ст.261).

Но установление мер ответственности, в частности, уголовной, опередило позитивное правовое регулирование, по крайней мере, на уровне специального федерального законодательства. Дело в том, правовое регулирование 5 , в частности, путем принятия Федерального закона «Об отходах производства и потребления», имело место позже, т.е. в 1998 г. Правда, Федеральным Собранием РФ еще в 1995 г. был принят Федеральный закон «Об обращении с радиоактивными отходами», но в декабре того же года Президент РФ использовал право вето, которое не было преодолено парламентариями. Лишь с середины 2000-х гг. специалисты вновь стали поднимать вопрос о необходимости разработать и принять специальный акт экологического (и атомного) права - Федеральный закон «О безопасном обращении с радиоактивными отходами» ${ }^{6}$. В настоящее время этот институт (подотрасль) экологического законодательства выглядит весьма разветвленной. Нормы, регламентирующие обращение с отходами, содержатся не только в упомянутом Федеральном законе об отходах производства и потребления», но и в Водном, Лесном и Земельном кодексах РФ, иных актах федерального уровня. В основном они касаются отдельных сторон этого процесса и/или некоторых видов отходов, их влияния на окружающую среду и здоровье людей и обычно содержат достаточно абстрактные запреты. Тем не менее, с учетом законодательства субъектов Российской Федерации и ведомственных актов следует согласиться с тем, что при всех имеющихся недостатках в стране действуют многочисленные правила, требования, стандарты, нормативы и иные предписания. И это вы-

\footnotetext{
${ }^{5}$ См.: Бринчук М.М. Экологическое право. Учебник. М.: Городец, 2009. С.354-367; Дубовик О.Л. Обращение с отходами и тенденции развития правового регулирования // Юридический мир. 2002. № 10. С. 48-56; Она же. Экологическое право. Учебник. 2-е изд. М.: Проспект, 2006. С.519-539 и др. работы.

${ }^{6}$ См.: Гирусов Ф.Э. Эколого-правовое регулирование обращения с радиоактивными отходами (сравнительно-правовое исследование). Автореф. канд. дисс., М.: ИГП РАН, 2005.
}

нуждает вернуться к проблеме соответствия действующего уголовного законодательства (применительно к ответственности за нарушение правил обращения с отходами) законодательству экологическому.

В развитие общей правовой реформы в Кодекс Российской Федерачии об административных правонарушениях, вступивший в силу в 2002 г., были включены обновленные нормы об ответственности за нарушение правил обращения с отходами. Причем подход законодателя к административной ответственности выразился в значимых по сравнению с КоАП РСФСР изменениях: введен общий состав (ст. 8.2 «Несоблюдение экологических и санитарно-эпидемиологических требований при обращении с отходами производства и потребления или иными опасными веществами») и ряд специальных составов (так, административная ответственность за нарушение правил обращения с отходами установлена, например, в части 5 ст. 8.13 «Нарушение правил охраны водных объектов») 7 .

Следовательно, в настоящее время Россия в целом реализует современные подходы к регулированию обращения с отходами, в том числе и касающиеся уголовной и административной ответственности за нарушение соответствующих правил ${ }^{8}$.

Но, тем не менее, возникает ряд проблем, касающихся как пробелов уголовного и административного законодательства, так и, в свою очередь, порождаемых их наличием трудностей правоприменения. Особо, подчеркнем еще раз, приходится обращать внимание на потребности согласования законотворческой практики с общими тенденциями создания и совершенствования норм об ответственности за нарушение правил обращения с отходами. Если, как многократно отмечалось в литературе, реформа УК РФ и КоАП РФ была осуществлена в русле новейших - по состоянию на начало 90-х гг.

\footnotetext{
${ }^{7}$ Подробнее см.: Комментарий к Кодексу Российской Федерации об административных правонарушениях / Под общей ред. Е.Н. Сидоренко, 4-е изд. М.: Проспект, 2004; Дубовик О.Л. Реформа законодательства об административной ответственности: экологические правонарушения//Экология производства. 2005. № 3. С.5-9; Она же. Административная ответственность за экологические правонарушения: предварительная оценка реформы законодательства // Экологическое право. 2002. № 2. С. 10-15; Она же. Шаг вперед к защите природы. Ответственность за экологические правонарушения по новому Кодексу // Закон. 2002. № 7. С. 35-41; Она же. Реформа законодательства об административной ответственности за экологические правонарушения // Юридический мир. 2002. № 4. С. 26-29.

8 Это прослеживается и по комментариям к действующему законодательству. См., например: Комментарий к КоАП РФ / Под общей ред. Н.Г. Салищевой. 6-е изд. М.: Проспект, 2008; Комментарий к УК РФ / Под ред. А.Э. Жалинского. 3-е изд. М.: Городец, 2010 и др.
} 
DOI: $10.7256 / 1811-9018.2014 .11 .13201$

При цитировании этой статьи сноска на доі обязательна

\section{Право и политика $11(179) \cdot 2014$}

прошлого века устремлений, то в наши дни приходится фиксировать отставание российского законодателя, по крайней мере, от общеевропейских тенденций.

Это касается отсутствия в российском законодательстве специальных норм об ответственности за действия продавцов и покупателей опасных отходов, за действия лиц, контролирующих мероприятия по сбору, обезвреживанию, транспортировке и перемещению отходов, их переработке и уничтожению, отказа от введения уголовной ответственности юридических лиц.

Если в отношении первой группы проблем еще можно ссылаться на формулировку части 1 ст.247 УК РФ, говорящей о нарушении правил, под которым комментаторы данной нормы обычно понимают любые правила и, следовательно, речь может идти о расширительном толковании, то во втором случае ситуация более сложная.

Проблема коллективной уголовной ответственности относится к числу наиболее спорных. Известны все аргументы «за» и «против». Не высказываясь здесь по сути, отметим, что к ее обсуждению, на наш взгляд, следует вернуться еще раз, учитывая и практику зарубежных стран, и практику отечественную - в сфере реализации запретов КоАП РФ и применения административных санкций к юридическим лицам за совершение ими нарушений экологического законодательства.

Наконец, вопрос о размерах санкций. По сравнению с уголовными кодексами иных стран УК РФ содержит мягкие меры за экологические преступления (а КоАП РФ - за экологические правонарушения). Не призывая к усилению репрессии в стране, все же следует еще раз взвесить соразмерность установленных законом санкций за экологические и экономические, транспортные и экологические и т.д. группы преступлений и оценить обоснованность учета ближайших и отдаленных, локальных, региональных и глобальных вредных последствий причиняемого преступными посягательствами на окружающую среду вреда.

В российской литературе, анализирующей уголовно-экологическое законодательство, пока что не отмечено каких-либо серьезных недостатков в формулировках статьи 247 УК РФ и ст.8.2 КоАП РФ. Напротив, указывается: введение в часть 1 ст.247 УК РФ состава поставления в опасность, т.е. за создание угрозы охраняемым правом благ, повысило потенциал данного уголовноправового запрета9. Субъектом Федерации (городом

\footnotetext{
${ }^{9}$ См.: Дубовик О.Л. Экологические преступления. Комментарий к главе 26 Уголовного кодекса Российской Федерации. М.: Спарк, 1998; Уголовное право России. Особенная часть. Учебник / Под ред. В.Н.Кудрявцева, В.В.Лунева, А.В.Наумова. М.: Юристъ, 2005.
}

Москва) согласно праву законодательной инициативы на основании этого вывода был еще несколько лет назад подготовлен проект изменений и дополнений статей гл.26 УК РФ. В нем были сформулированы предложения о расширении круга составов поставления в опасность. В частности, обосновывалась необходимость их введения в части первые ст. 246 «Нарушение правил охраны окружающей среды при производстве работ», ст.248 «Нарушение правил безопасности при обращении с микробиологическими либо другими биологическими агентами или токсинами», ст. 250 «Загрязнение вод», ст. 251 «Загрязнение атмосферы», ст.252 «Загрязнение морской среды» и некоторые другие. Проект, к сожалению, не получил одобрения Верховного Суда РФ.

\section{Оценка предложений по совершенствованию уголовного и административного законодательства об ответственности за нарушение правил обращения с отходами.}

Основные предложения, высказываемые в литературе и на конференциях сводятся к усилению санкций за экологические преступления и правонарушения. С этим - по крайней мере - применительно к экологическим преступлениям согласиться трудно, поскольку реформа системы наказаний, проведенная Федеральным законом от 8 декабря 2004 г. была направлена на замену уголовных штрафных санкций, исчисляемых ранее исходя из минимальных размеров оплаты труда или их эквивалента по доходам осужденного за определенный период, на твердо определенные размеры таковых.

Кроме того, в последнее время были высказаны также иные предложения. Так, ныне обсуждается в проекте изменений Уголовного кодекса РФ предложение об ограничении возможности применения условного осуждения к лицам, совершившим тяжкие и особо тяжкие преступления. Применительно к экологическим преступлениям реализация данного предложения вызовет не позитивный, но негативный эффект. Дело в том, что в главе 26 УК РФ «Экологические преступления» содержится всего две статьи, устанавливающие ответственность за тяжкие преступления. Это: статья 247 «Нарушение правил обращения экологически опасных отходов, транспортировки, захоронения, использования или иного обращения радиоактивных, бактериологических, химических веществ и отходов с нарушением установленных правил, а равно совершенные в зоне экологического бедствия или в зоне чрезвычайной экологической ситуации, повлекшие по неосторожности смерть человека либо массовое заболевание людей, 
DOI: $10.7256 / 1811-9018.2014 .11 .13201$

При цитировании этой статьи сноска на dоі обязательна

Человек и окружающая среда

предусмотрена санкция в виде лишения свободы на срок от трех до восьми лет; ст. 261 «Уничтожение и повреждение лесов», предусматривающая наряду с иными видами наказания лишение свободы на срок до семи лет за уничтожение или повреждение лесов, а равно насаждений, не входящих в лесной фонд, путем поджога, иным общеопасным способом либо в результате загрязнения вредными веществами, отходами, выбросами или сбросами.

Еще один аргумент. Можно полагать, что в подавляющем большинстве случаев совершения деяний, предусмотренных ст. 247 УК РФ, субъектами преступления являются должностные лица и ответственные работники предприятий и организаций, специалисты, личность которых не характеризуется устойчивой криминальностью. Кроме того, известно, что во многих случаях совершение такого рода преступлений связано со сложными производственно-техническими условиями, изношенностью оборудования и т.п. факторами. Распространение на данную категорию лиц, преступивших закон, правила, не позволяющего использовать условное осуждение, по меньшей мере, не усилит превентивную функцию данного уголовно-правового запрета. Более того, оно может сузить и применяемость административных санкций за аналогичные правонарушения.

Но в современный период с учетом социально-экологической и криминологической ситуаций в стране, как уже говорилось, следует вновь обратиться к задаче совершенствования уголовной ответственности за экологические преступления и, в первую очередь, за нарушение правил обращения с отходами с учетом новейших тенденций эскалации экологической преступности и наносимых ею вредных для окружающей среды и здоровья людей последствий. При этом важно учесть и опыт зарубежных стран. Не менее актуальна и задача предупреждения таких нарушений, решаемая - среди прочего - путем повышения экологического контроля и распространения экологического образования и воспитания.

\section{Международное и зарубежное право об отходах.}

Следует указать, что наряду с международноправовым регулированием (Конвенция по предотвращению загрязнения моря сбросами отходов и других материалов - 1972 г., Объединенная конвенция о безопасности обращения с отработавшим топливом и о безопасности обращения с радиоактивными отходами - 1997 г., Базельская конвенция о контроле за трансграничной перевозкой опасных отходов и их удалени- ем - 1989 г. и др.) в рамках объединений государств, в первую очередь, в Европейском Союзе ${ }^{10}$ и во входящих в него государствах, как и в иных странах, были приняты многочисленные законодательные акты и документы (стратегии, концепции, программы и проч.). В этих актах сформулированы принципы политики в области обращения с отходами, отдельными их видами, как правило, наиболее опасными для окружающей среды и здоровья людей.

Весьма интенсивно используются и меры уголовного законодательства. Так, начиная с 1979 г. (Конгресс Международной ассоциации уголовного права в Гамбурге), где впервые была сформулирована цель усиления охраны окружающей среды от преступных посягательств, в том числе и совершаемых путем нарушения законодательства об обращении с отходами, эти меры оценивались как все более необходимые. На Конференции в Рио-де-Жанейро (1992 г.) усиление уголовной ответственности за экологические преступления было признано всеми участниками неотложным шагом.

Еще более решительные меры были осуществлены европейским законодателем в Конвенции о защите окружающей среды средствами уголовного закона (Страсбург, 1998 г.). По статье 2 рекомендовалось странам-участницам Конвенции ввести в уголовные кодексы ответственность за противоправное удаление, переработку, хранение, транспортировку, экспорт или импорт опасных отходов, если это вызвало или могло вызвать смерть человека или существенный вред его здоровью или существенное ухудшение качества воздуха, земли, вод, животных или растений. В результате во многих странах, как вступивших в Конвенцию, так и не ставших ее участницами, были проведены кардинальные реформы уголовно-экологического законодательства: выделены главы/разделы об экологических преступлениях, предусмотрена уголовная ответственность за нарушение правил обращения с отходами.

Более того, 19 ноября 2008 г. Европейские парламент и Совет приняли Директиву 2008/99/EC. Государства-члены ЕС обязываются в течение двух

\footnotetext{
${ }^{10}$ См., в частности, директивы ЕС: об отходах (Рамочная) 1975 г., о полигоне для складирования отходов 1999 г., о сжигании отходов 2000 г., об опасных отходах 1991 г., об упаковках и отходах об упаковок 1994 г., о сжигании опасных отходов 1989 г., об удалении отходов масел 1975 г., об отходах производства двуокиси титана 1978 г. и многие др. Изменения указанных документов см.: Кремер Л., Винтер Г. Экологическое право Европейского Союза. М.: Городец, 2007. С.111-122.; Степаненко В.С. Правовое регулирование обращения с отходами: Сравнительный анализ европейского, германского и польского законодательства/Под ред. О.Л. Дубовик. М.: НИА-Природа, 2008. С.9-13.
} 
DOI: $10.7256 / 1811-9018.2014 .11 .13201$

При цитировании этой статьи сноска на dоі обязательна

\section{Право и политика $11(179) \cdot 2014$}

лет ввести в национальное законодательство ответственность за противоправные умышленные или совершенные по грубой небрежности сбор, транспортировку, переработку или уничтожение отходов, в том числе надзор за этой деятельностью или дальнейшее обезвреживание отходов, а также действия, предпринимаемые впоследствии продавцом или посредником (управление отходами), которые причиняют или могут причинить смерть или тяжкий вред здоровью либо существенный вред качеству воздуха, недр, вод либо животным или растениям, а также за перемещение отходов, если это деяние осуществляется в нарушении ряда предписаний ЕС в значительных объемах - без учета того, происходит ли оно в рамках одного перемещения или нескольких перемещений, которые связаны между собой ${ }^{11}$. Как видим, данная Директива в значительной степени уточнила положения Европейской конвенции и других актов в отношении признаков состава преступного посягательства на порядок обращения с отходами.

\section{Библиография:}

1. Бринчук М.М. Экологическое право. Учебник. М.:Городец, 2009. С.354-367.

2. Гирусов Ф.Э. Эколого-правовое регулирование обращения с радиоактивными отходами (сравнительно-правовое исследование). Автореф. канд. дисс., М.: ИГП РАН, 2005.

3. Государственный доклад о состоянии и об охране окружающей среды Российской Федерации в 2012 г. М.: МПР России, 2014. С.420-421.

4. Доклад о состоянии окружающей среды в городе Москве в 2012 г. М.: Департамент природопользования и охраны окружающей среды при Правительстве города Москвы, 2013. С.63.

5. Дубовик О.Л. Реформа законодательства об административной ответственности за экологические правонарушения // Юридический мир. 2002. № 4. С. 26-29.

6. Дубовик О.Л. Административная ответственность за экологические правонарушения: предварительная оценка реформы законодательства // Экологическое право. 2002. № 2. С. 10-15.

7. Дубовик О.Л. Обращение с отходами и тенденции развития правового регулирования // Юридический мир. 2002. № 10. С. 48-56.

8. Дубовик О.Л. Реформа законодательства об административной ответственности: экологические правонарушения// Экология производства. 2005. № 3. С.5-9.

9. Дубовик О.Л. Шаг вперед к защите природы. Ответственность за экологические правонарушения по новому Кодексу // Закон. 2002. № 7. С. 35-41.

10. Дубовик О.Л. Экологические преступления. Комментарий к главе 26 Уголовного кодекса Российской Федерации. М.: Спарк, 1998.

11. Дубовик О.Л. Экологическое право. Учебник. 2-е изд. М.: Проспект, 2006. С.519-539.

12. Дубовик О.Л., Жалинский А.Э. Причины экологических преступлений. Комментарий к Кодексу РСФСР об административных правонарушениях / Под ред. И. И. Веремеенко, Н. Г. Самищевой, М. С. Студеникиной. М., 1988,Спарк. С. 249-255

13. Дубовик О.Л., Кремер Л.,Компф Ф. Экологическая преступность в Европе. М.: Городец. 2010 г. С.8-11.

14. Комментарий к КоАП РФ / Под общей ред. Н.Г. Салищевой. 6-е изд. М.: Проспект, 2008.

15. Комментарий к Кодексу Российской Федерации об административных правонарушениях/Под общей ред. Е.Н. Сидоренко, 4-е изд. М.: Проспект, 2004.

16. Комментарий к УК РФ / Под ред. А.Э. Жалинского. 3-е изд. М.: Городец, 2010 г.

17. Кремер Л., Винтер Г. Экологическое право Европейского Союза. М.: Городец, 2007. С.111-122.

18. Курс российского уголовного права. Особенная часть / Под ред. В.Н. Кудрявцева и А.В. Наумова. М.: Спарк, 2002.

19. Степаненко В.С. Правовое регулирование обращения с отходами: Сравнительный анализ европейского, германского и польского законодательства / Под ред. О.Л. Дубовик. М.: НИА-Природа, 2008. С.9-13.

20. Уголовное право России. Особенная часть.Учебник / Под ред. В.Н.Кудрявцева, В.В.Лунеева, А.В.Наумова. М.: Юристъ, 2005.

21. Юридическая конфликтология / Под ред. В.Н. Кудрявцева. М.: ИГП РАН, 1994.

22. Дубовик О.Л. Роль директив в правовом регулировании охраны окружающей среды в Европейском Союзе // Международное право и международные организации / International Law and International Organizations. - 2014. - 1. C. 107-116. DOI: $10.7256 / 2226-6305.2014 .1 .10506$.

23. Редникова Т.В.. Охрана компонентов биологического разнообразия и правовое регулирование обеспечения равного доступа к извлекаемым из них благам: реализация положений конвенции о биологическом разнообразии // Международное право и международные организации / International Law and International Organizations. - 2013. - № 4. - C. 104-107. DOI: $10.7256 / 2226-6305.2013 .4 .10519$

24. Куделькин Н.С.. Понятие «загрязнение морской среды» в российском и международном праве // Международное право и международные организации / International Law and International Organizations. - 2013. - № 4. - C. 104-107. DOI: $10.7256 / 2226-6305.2013 .4 .10566$

\footnotetext{
${ }^{11}$ Подробнее см.: Дубовик О.Л., Кремер Л., Компф Ф. Экологическая преступность в Европе. М.: Городец. 2010 г. С.8-11.
} 
DOI: $10.7256 / 1811-9018.2014 .11 .13201$

При цитировании этой статьи сноска на dоі обязательна

Человек и окружающая среда

25. Степаненко В.С.. Принципы экологического права ЕС // Международное право и международные организации / International Law and International Organizations. - 2013. - № 4. - C. 104-107. DOI: 10.7256/2226-6305.2013.4.10075

26. Анохин С.А.. Роль органов внутренних дел в осуществлении правовой охраны окружающей среды. // Полицейская деятельность. - 2013. - № 6. - С. 104-107. DOI: 10.7256/2222-1964.2013.6.10431

27. Урсул А.Д. Право устойчивого развития: концептуально-методологические проблемы становления // NB: Вопросы права и политики. - 2013. - № 6. - C.63-134. DOI: 10.7256/2305-9699.2013.6.2309. URL: http://e-notabene.ru/lr/article_2309.html

28. Урсул А.Д., Урсул Т.А. Глобализация в перспективе устойчивого будущего // NB: Вопросы права и политики. -2013. - № 5. - C.1-63. DOI: 10.7256/2305-9699.2013.5.794. URL: http://e-notabene.ru/lr/article_794.html

29. В.Н. Шеломенцев. Конституционно-правовое регулирование в экологической сфере // Политика и Общество. - 2013. - № 4. - C. 104-107. DOI: 10.7256/1812-8696.2013.04.2

30. О.Л. Дубовик. Рецензия на книгу: Международное экологическое право: учебник / отв. ред. Р.М. Валеев. М.: Статут, 2012. - 639 с // Международное право и международные организации / International Law and International Organizations. - 2013. - № 1. - C. 104-107. DOI: 10.7256/2226-6305.2013.01.11

31. А.А. Никифоров. Действие международных договоров в сфере охраны окружающей среды в национальном праве стран Северной Европы // Международное право и международные организации / International Law and International Organizations. - 2013. - № 1. - C. 104-107. DOI: 10.7256/2226-6305.2013.01.10

32. А.А. Никифоров. Международно-правовая охрана окружающей среды в странах Северной Европы // Международное право и международные организации / International Law and International Organizations. - 2012. - № 4. - C. 104-107.

33. Тюлин Р.А.. Некоторые аспекты совершенствования административного законодательства в сфере охраны окружающей среды // Административное и муниципальное право. - 2012. - № 11. - С. 104-107.

34. А. В. Вусов. Эконометрический анализ учета влияния экологического вреда на стоимость недвижимости // Национальная безопасность / nota bene. - 2012. - № 4. - С. 104-107

\section{References (transliterated):}

1. Brinchuk M.M. Ekologicheskoe pravo. Uchebnik. M.:Gorodets, 2009. S.354-367.

2. Girusov F.E. Ekologo-pravovoe regulirovanie obrashcheniya s radioaktivnymi otkhodami (sravnitel'no-pravovoe issledovanie). Avtoref. kand. diss., M.: IGP RAN, 2005.

3. Dubovik O.L. Reforma zakonodatel'stva ob administrativnoi otvetstvennosti za ekologicheskie pravonarusheniya // Yuridicheskii mir. 2002. № 4. S. 26-29.

4. Dubovik O.L. Administrativnaya otvetstvennost' za ekologicheskie pravonarusheniya: predvaritel'naya otsenka reformy zakonodatel'stva // Ekologicheskoe pravo. 2002. № 2. S. 10-15.

5. Dubovik O.L. Obrashchenie s otkhodami i tendentsii razvitiya pravovogo regulirovaniya // Yuridicheskii mir. 2002. № 10. S. 48-56.

6. Dubovik O.L. Reforma zakonodatel'stva ob administrativnoi otvetstvennosti: ekologicheskie pravonarusheniya//Ekologiya proizvodstva. 2005. № 3. S.5-9.

7. Dubovik O.L. Shag vpered k zashchite prirody. Otvetstvennost' za ekologicheskie pravonarusheniya po novomu Kodeksu // Zakon. 2002. № 7. S. 35-41.

8. Dubovik O.L. Ekologicheskie prestupleniya. Kommentarii k glave 26 Ugolovnogo kodeksa Rossiiskoi Federatsii. M.: Spark, 1998.

9. Dubovik O.L. Ekologicheskoe pravo. Uchebnik. 2-e izd. M.: Prospekt, 2006. S.519-539.

10. Dubovik O.L., Zhalinskii A.E. Prichiny ekologicheskikh prestuplenii. Kommentarii k Kodeksu RSFSR ob administrativnykh pravonarusheniyakh / Pod red. I. I. Veremeenko, N. G. Samishchevoi, M. S. Studenikinoi. M., 1988,Spark. S. 249-255

11. Dubovik O.L., Kremer L.,Kompf F. Ekologicheskaya prestupnost’ v Evrope. M.: Gorodets. 2010 g. S.8-11.

12. Kremer L., Vinter G. Ekologicheskoe pravo Evropeiskogo Soyuza. M.: Gorodets, 2007. S.111-122.

13. Stepanenko V.S. Pravovoe regulirovanie obrashcheniya s otkhodami: Sravnitel'nyi analiz evropeiskogo, germanskogo i pol'skogo zakonodatel'stva / Pod red. O.L. Dubovik. M.: NIA-Priroda, 2008. S.9-13.

14. Dubovik O.L. Rol' direktiv v pravovom regulirovanii okhrany okruzhayushchei sredy v Evropeiskom Soyuze // Mezhdunarodnoe pravo i mezhdunarodnye organizatsii / International Law and International Organizations. - 2014. - 1. - C. 107-116. DOI: 10.7256/2226-6305.2014.1.10506.

15. Rednikova T.V.. Okhrana komponentov biologicheskogo raznoobraziya i pravovoe regulirovanie obespecheniya ravnogo dostupa $\mathrm{k}$ izvlekaemym iz nikh blagam: realizatsiya polozhenii konventsii o biologicheskom raznoobrazii // Mezhdunarodnoe pravo $\mathrm{i}$ mezhdunarodnye organizatsii / International Law and International Organizations. - 2013. - № 4. - S. 104-107. DOI: 10.7256/22266305.2013.4.10519

16. Kudel'kin N.S.. Ponyatie «zagryaznenie morskoi sredy» v rossiiskom i mezhdunarodnom prave // Mezhdunarodnoe pravo i mezhdunarodnye organizatsii / International Law and International Organizations. - 2013. - № 4. - S. 104-107. DOI: 10.7256/22266305.2013.4.10566

17. Stepanenko V.S.. Printsipy ekologicheskogo prava ES // Mezhdunarodnoe pravo i mezhdunarodnye organizatsii / International Law and International Organizations. - 2013. - № 4. - S. 104-107. DOI: 10.7256/2226-6305.2013.4.10075

18. Anokhin S.A.. Rol' organov vnutrennikh del v osushchestvlenii pravovoi okhrany okruzhayushchei sredy. // Politseiskaya deyatel'nost'. - 2013. - № 6. - S. 104-107. DOI: 10.7256/2222-1964.2013.6.10431 
DOI: $10.7256 / 1811-9018.2014 .11 .13201$

При цитировании этой статьи сноска на доі обязательна

\section{Право и политика $11(179) \cdot 2014$}

19. Ursul A.D. Pravo ustoichivogo razvitiya: kontseptual'no-metodologicheskie problemy stanovleniya // NB: Voprosy prava i politiki. - 2013. - № 6. - S.63-134. DOI: 10.7256/2305-9699.2013.6.2309. URL: http://e-notabene.ru/lr/article_2309.html

20. Ursul A.D., Ursul T.A. Globalizatsiya v perspektive ustoichivogo budushchego // NB: Voprosy prava i politiki. - 2013. - № 5. S.1-63. DOI: 10.7256/2305-9699.2013.5.794. URL: http://e-notabene.ru/lr/article_794.html

21. V.N. Shelomentsev. Konstitutsionno-pravovoe regulirovanie v ekologicheskoi sfere // Politika i Obshchestvo. - 2013. - № 4. S. 104-107. DOI: $10.7256 / 1812-8696.2013 .04 .2$

22. O.L. Dubovik. Retsenziya na knigu: Mezhdunarodnoe ekologicheskoe pravo: uchebnik / otv. red. R.M. Valeev. M.: Statut, 2012. - 639 s // Mezhdunarodnoe pravo i mezhdunarodnye organizatsii / International Law and International Organizations. - 2013. - № 1. - S. 104-107. DOI: 10.7256/2226-6305.2013.01.11

23. A.A. Nikiforov. Deistvie mezhdunarodnykh dogovorov v sfere okhrany okruzhayushchei sredy v natsional'nom prave stran Severnoi Evropy // Mezhdunarodnoe pravo i mezhdunarodnye organizatsii / International Law and International Organizations. - 2013. - № 1. - S. 104-107. DOI: 10.7256/2226-6305.2013.01.10

24. A.A. Nikiforov. Mezhdunarodno-pravovaya okhrana okruzhayushchei sredy v stranakh Severnoi Evropy // Mezhdunarodnoe pravo i mezhdunarodnye organizatsii / International Law and International Organizations. - 2012. - № 4. - S. $104-107$.

25. Tyulin R.A.. Nekotorye aspekty sovershenstvovaniya administrativnogo zakonodatel'stva v sfere okhrany okruzhayushchei sredy // Administrativnoe i munitsipal'noe pravo. - 2012. - № 11. - S. 104-107.

26. A. V. Vusov. Ekonometricheskii analiz ucheta vliyaniya ekologicheskogo vreda na stoimost' nedvizhimosti // Natsional'naya bezopasnost' / nota bene. - 2012. - № 4. - S. 104-107 